\title{
Wound Healing Properties and Structural Analysis of Four Geographical Areas' Natural Clays
}

\author{
Zahra A. Amin \\ Department of Pharmacognosy, College of Pharmacy, Hawler Medical University Erbil, Erbil 44001, Iraq
}

\begin{abstract}
Clays are fine particle materials that harden after drying. The difference in their structure is the key to their efficacy and their subsequent application. The current study aims to evaluate the wound healing property of four countries (C1:Iraq, C2: Turkey, C3:Azerbaijan and C4:Russia) clay samples by excision model using Sprague dawley rats also the chemical analysis of the samples was performed using X-ray diffraction (XRD) and X-ray Fluorescence (XRF) methods. Results revealed that the best wound healing activities were given by $\mathrm{C} 1, \mathrm{C} 3, \mathrm{C} 4$ and $\mathrm{C} 2$ respectively with healing percentages $(76 \%, 71 \%, 62 \%$, and $60 \%)$, respectively. XRD results revealed the presence of Calcium carbonate and CalciumMagnesium carbonate in C1, Dolomite and Calcium-Magnesium carbonate in C2, Cobalt Tantalum Sulfide in C3, Finally Quartz and Silicon Oxide in C4. On the other hand, XRF analysis showed the appearance of different major and trace elements with different quantities in each clay type. We conclude that different countries clays enclose wound healing property with diverse ranges and this diversity is due to their chemical and mineral structures.
\end{abstract}

Index Terms-Natural clay; wound healing; rats; X-ray diffraction; X-ray fluorescence.

\section{INTRODUCTION}

Worldwide many people are experiencing different types of skin wounds and the synthetic compounds are of less use day by day because they are environmental pollutants and take a long time circulating to the nature that is why there is an increase in the using of natural remedies for the treatment and healing of the wounds. In the developing countries, around $80 \%$ of their population are depending on the natural substances to treat their infections (Qureshi, Khatoon and Ahmed, 2015). The evolution and progress of wound therapies and advanced strategies with new techniques are observed over the years; however, skin wound treatments are categorized generally as "Regenerative" or "Conventional". Regenerative therapy aims to restore skin to its original function, reestablishing damaged cells and skin tissue without scarring while conventional therapy leads to the formation of

ARO-The Scientific Journal of Koya University

Vol. X, No.1 (2022), Article ID: ARO.10889, 5 pages DOI: $10.14500 /$ aro. 10889

Received: 08 October 2021; Accepted: 12 January 2022

Regular research paper: Published: 15 February 2022

Corresponding author's email: zahraa.alnajaar@hmu.edu.krd Copyright (C) 2022 Zahra A. Amin. This is an open access article distributed under the Creative Commons Attribution License. scars (Tottoli, et al., 2020). Clay minerals healing efficacy were discovered many years ago and have been applied in Medicine for different purposes like spas, pharmaceutical formulations and aesthetic medicine. They are either orally administered for uses as laxatives, gastrointestinal protectors, anti-diarrhetics or as topical applications in cosmetics and dermatological protectors (Carretero, 2002) also clays were given to farm animals for the detoxification purposes and alleviation of gastrointestinal diseases. (Slamova, et al., 2011). Moreover, latest studies have documented the potential of clay minerals in the nanomedicine field regarding their beneficial effects on skin proliferation, cellular adhesion, and differentiation (Viseras, et al., 2019). In addition, the clay minerals were used to moisturize and clean the skin and to reduce acne, lipodystrophies and cellulite (Arab and Alshikh, 2012) (Williams and Haydel, 2010) investigated the antibacterial activity of natural clays and they found that the antioxidant state and the $\mathrm{pH}$ are the key of the reactions control and the chemistry of the bacterial cell wall. In addition, clays are proposed not to kill bacteria directly but may enclose soothing effects which are palliative (Williams, 2019). Other researchers proved that the clay material destroyed many bacterial strains, including Methicillin-resistant Staphylococcus aureus, Escherichia coli, Pseudomonas aeruginosa, and Salmonella enterica (Gaskell and Hamilton, 2014). Other pharmacological uses of clay include treatment of gastrointestinal diseases, applied topically to treat skin disorders, and have been taken orally to manage chronic or urgent diarrhea, and rheumatism. The mechanism of action was suggested to be due to their high porosity, large specific surface area, high adsorption and exchange capacities (Tang, et al., 2005). The chemical composition of natural clays includes silica, magnesium, aluminum, little iron substitutes and low quantities of sodium, potassium and calcium are existent as well. Depending on their ionic structure, these minerals can be classified into nine groups: pyrophyllite-talc, kaolin-serpentine, vermiculite, mica, chlorite, smectite, interstratified clay minerals (e.g., rectorite, tosudite, and corrensite), sepiolite-palygorskite, and allophane-imogolite (Wilson, 1994). These inorganic compositions of clays has been documented to improve and treat skin wounds through three different mechanisms, (1) physically by water vapor transmission and mechanical resistance, (2) chemically by hemostasis or adsorption of 
moisture and release of drugs, and (3) biologically by their antibacterial/antimicrobial effects and improving the healing process(García-Villén, et al., 2020). The aim of the present study was to compare the chemical composition of four clay samples obtained from different geographical areas and to evaluate the efficacy of the topical application of these clay samples in accelerating excision wound healing in vivo in experimental rat model.

\section{MATERIALS AND METHODS}

\section{A. Clay Preparation and Analysis}

Four types of natural clays were collected from four different countries: Iraq (C1), Turkey (C2), Azerbaijan (C3), and Russia (C4), their different external views or appearances are shown in Fig. 1. The clays were grinded and prepared freshly every day by mixing with local mineral waters, which contain a unique balance of salts in a ratio of $2: 1$ water and clay, respectively. The mineral content of the clays were tested at Civil Engineering laboratory, Research Center, Koya University, to perform X-Ray Diffraction (XRD) technique type Panalytical Empyrean with $\mathrm{CuK \alpha}$ radiation. The elemental composition and their energies were determined using energy dispersive X-ray Fluorescence (EDXRF).

\section{B. In Vivo Wound Healing (Excision Model)}

Forty male Wistar rats (weighing 250-300 g) were randomly divided into 5 groups. Round seal was used to excise a uniform area of $2 \mathrm{~cm}$ in diameter from the nape of dorsal neck of all the rats. Then different treatments were applied as described in following:

Group 1 (Control) rats were topically applied with MEBO cream twice a day

Group 2 rats were topically dressed with $2 \mathrm{~mL}$ of C1 sample twice a day.

Group3 rats were topically dressed with $2 \mathrm{~mL}$ of C2 sample twice a day.

Group 4 rats were topically dressed with $2 \mathrm{~mL}$ of C3 sample twice a day.

Group 5 rats were topically dressed with $2 \mathrm{~mL}$ of C4 sample twice a day.

The wound area was noted by measuring the contraction area. Manually, the wound areas were traced and calculated in square millimeters. The wound closure area and closure percentage rate were measured at days 0,5 , and 10 of the experiment. The wound area was measured immediately by placing a transparent tracing paper over the wound and tracing it out. The tracing paper was placed on $1 \mathrm{~mm} 2$ graph sheet and traced out. The squares were counted and the area recorded. Then, the percentage of wound closure was calculated following the formula: Wound closure $(\%)=1-(A d A 0) * 100$, (1) where $A 0$ is wound area at day zero and $A d$ is wound area on corresponding day (Amin, et al., 2015).

\section{Statistical Analysis}

All values are reported as mean \pm SEM. and the statistical significance of differences among groups was assessed using one-way ANOVA. A value of (0.05) was considered significant.

\section{RESULTS}

Table 1 shows the effects of different treatments on the percentage of wound healing at different days after surgery, at day 0 no significant difference was found between groups that shows the accuracy of the work whereas significant results were found on day 5 of the treatment in which $\mathrm{C} 1$ and $\mathrm{C} 3$ clays showed wound closure percentage of (48\% and $45 \%)$, respectively, which are comparable to MEBO group $(43 \%)$. Moreover, remarkable results were observed at day $10^{\text {th }}$ of the surgery in which the wound closure percentage were $(76 \%, 60 \%, 71 \%$, and $62 \%$ ) for $\mathrm{C} 1, \mathrm{C} 2, \mathrm{C} 3$, and $\mathrm{C} 4$ groups, respectively. The $\mathrm{C} 1$ and $\mathrm{C} 3$ group's results were better than the MEBO control group (64\%). These results confirmed macroscopically (as shown in Fig. 2), as seen groups C1

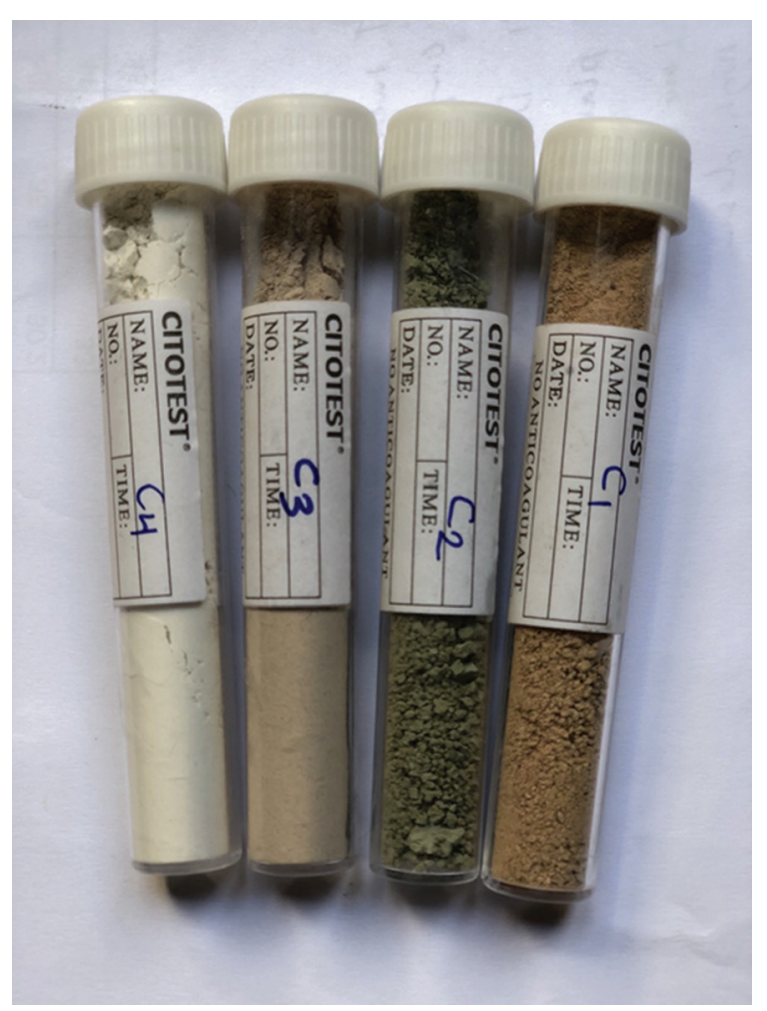

Fig. 1. The external view of the clay samples; $\mathrm{C} 1$ clay from Iraq, C2 clay from Turkey, C3 clay from Azerbaijan and C4 clay from Russia.

TABLE I

Wound Healing Measurements of Experimental Rats after Exposure to DifFerent TREatments.

\begin{tabular}{|c|c|c|c|c|c|}
\hline \multirow[t]{2}{*}{ Groups } & \multirow{2}{*}{$\begin{array}{c}\text { Day } 0 \\
\begin{array}{c}\text { Wound } \\
\text { area }\end{array}\end{array}$} & \multicolumn{2}{|c|}{ Day 5} & \multicolumn{2}{|c|}{ Day 10} \\
\hline & & $\begin{array}{c}\text { Wound } \\
\text { area }\end{array}$ & $\begin{array}{c}\text { Wound } \\
\text { closure \% }\end{array}$ & $\begin{array}{c}\text { Wound } \\
\text { area }\end{array}$ & $\begin{array}{c}\text { Wound } \\
\text { closure \% }\end{array}$ \\
\hline MEBO & $332 \pm 2.4$ & $190 \pm 2.1^{*}$ & 43 & $120 \pm 2.1 *$ & 64 \\
\hline $\mathrm{C} 1$ & $339 \pm 0.9$ & $175 \pm 1.7 *$ & 48 & $81 \pm 1.6^{*}$ & 76 \\
\hline $\mathrm{C} 2$ & $340 \pm 0.7$ & $231 \pm 1.4$ & 32 & $137 \pm 1.5^{*}$ & 60 \\
\hline $\mathrm{C} 3$ & $342 \pm 2.1$ & $187 \pm 1.1^{*}$ & 45 & $100 \pm 1.3^{*}$ & 71 \\
\hline $\mathrm{C} 4$ & $338 \pm 1.4$ & $225 \pm 3.1$ & 33 & $130 \pm 3.3^{*}$ & 62 \\
\hline
\end{tabular}

Data expressed as Mean \pm SEM, $P$ value considered significant when is $<0.05$ 
and $\mathrm{C} 3$ showed a significant re-epithelialization with sign of dermal healing as compared to MEBO group.

$\mathrm{XRD}$ results showed that the main peaks were related to magnesium calcite (chemical formula $\mathrm{C}_{1} \mathrm{Ca}_{0.94} \mathrm{Mg}_{0.06} \mathrm{O}_{3}$ ) and magnesium calcium carbonate (chemical formula $\mathrm{Mg}_{0.06}$ $\left.\mathrm{Ca}_{0.94}\right)\left(\mathrm{CO}_{3}\right)$ ) in $\mathrm{C} 1$ sample (density $=2.75 \mathrm{~g} / \mathrm{cm}^{3}$ ) as shown in Fig. 3a. Whereas, the peaks of $\mathrm{C} 2$ sample (density = $2.88 \mathrm{~g} / \mathrm{cm}^{3}$ ) were related to Dolomite (chemical formula $\mathrm{C}_{2}$ $\mathrm{Ca}_{1} \mathrm{Mg}_{1} \mathrm{O}_{6}$ ) and Calcium Magnesium Carbonate (chemical formula $\mathrm{CaMg}\left(\mathrm{CO}_{3}\right)$ ) Fig. 3b. In addition to Cobalt Tantalum Sulfide (chemical formula $\mathrm{CO}_{2} \mathrm{~S}_{6} \mathrm{Ta}_{9}$ ) in $\mathrm{C} 3$ $\left(\right.$ density $\left.=10.77 \mathrm{~g} / \mathrm{cm}^{3}\right)$, finally Quartz (chemical formula
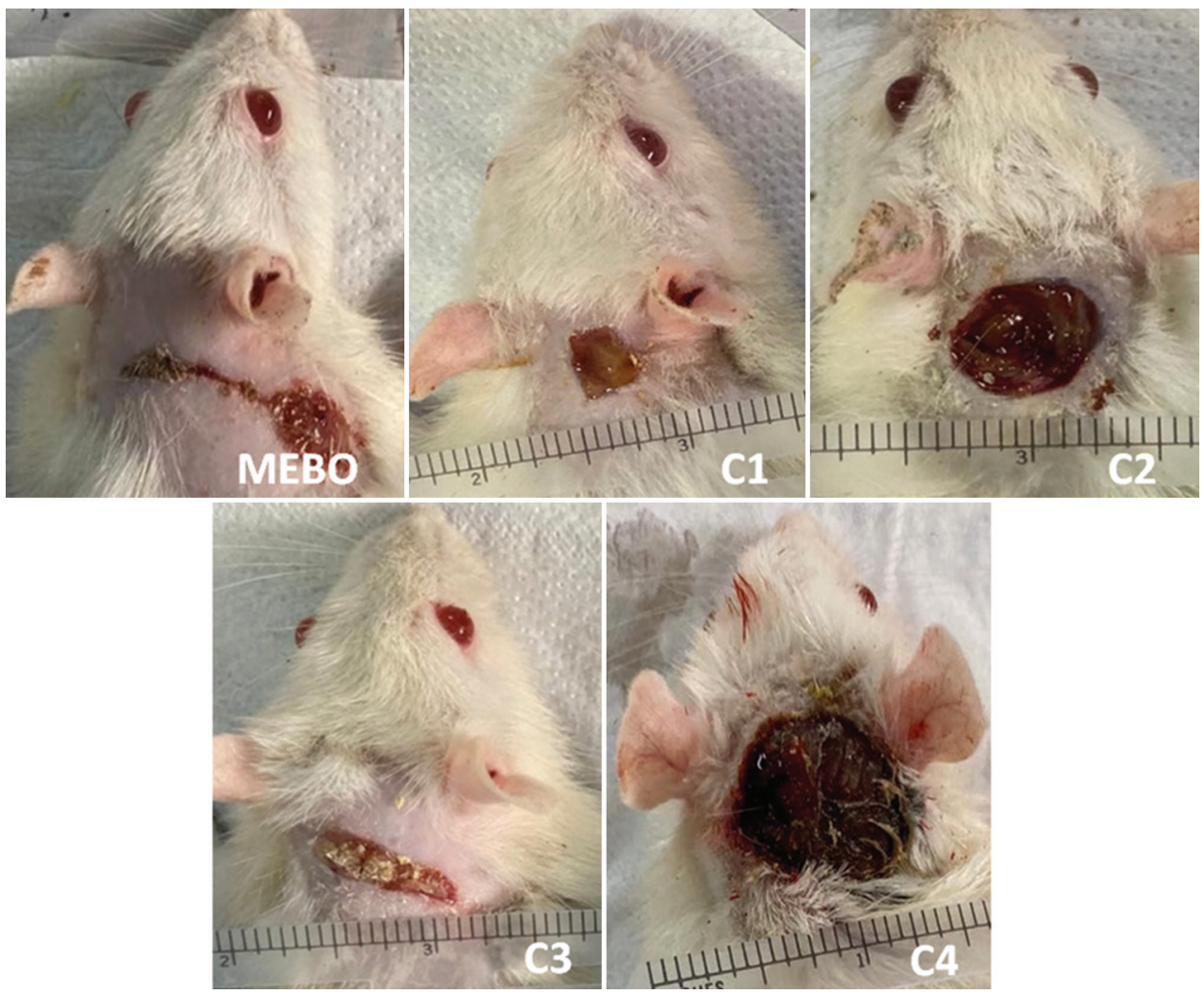

Fig. 2. Macroscopic appearance of excision wound healing area on rat skin at day 10 after surgery within different groups of treatments.
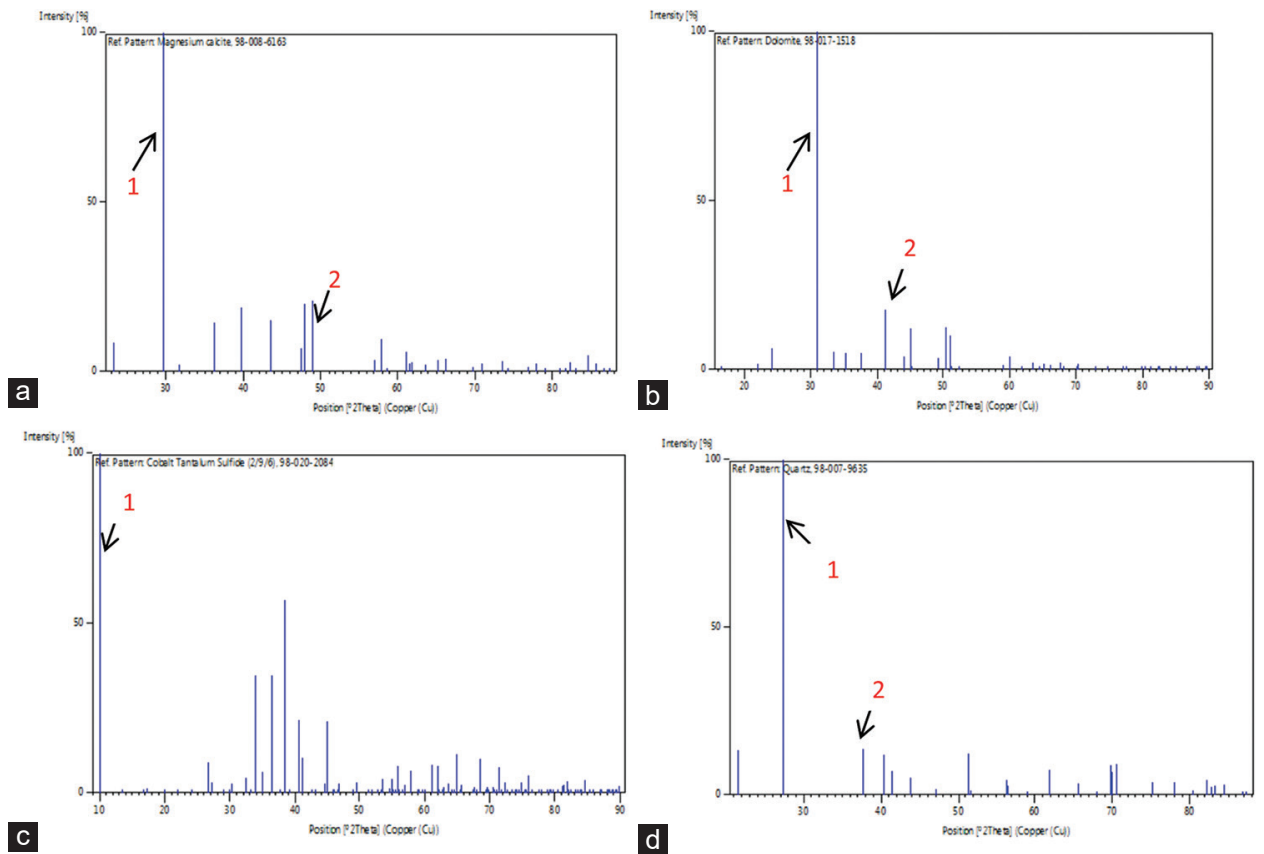

Fig. 3. The X-Ray Diffraction analysis of the clay samples. (a) C1 sample: peak 1 Magnesium Calcite peak 2 Magnesium Calcium carbonate, (b) C1 sample: peak 1 Dolomite peak 2 Calcium Magnesium Carbonate, (c) C3 sample: peak 1 Cobalt Tantalum Sulfide peak 2 Silica Oxide (d) C4 sample: peak 1 Quartz. 
$\mathrm{O}_{2} \mathrm{Si}_{1}$ ), and Silicon Oxide (chemical formula $\mathrm{SiO}_{2}$ ) in C4 sample (density $=2.75 \mathrm{~g} / \mathrm{cm}^{3}$ ), respectively.

On the other hand, the X-ray Fluorescence (XRF) analysis of the clay samples showed that the Silica or Quartz (SiO2), Calcium Oxide $(\mathrm{CaO})$, Aluminum Oxide $(\mathrm{Al} 2 \mathrm{O} 3)$ and the Iron III or Ferric Oxide (Fe2O3) are the main elements of all types of clays with the appearance of few other trace elements in a lower quantities (Table 2).

\section{Discussion}

Experimental animals wound healing models have been studied widely in the last years. Nowadays, $80 \%$ of population depend on natural remedies to maintain wound care management (Qureshi, Khatoon and Ahmed, 2015). Indeed, the wound healing property of clays was well defined (Ferrell, 2008) in vitro and in vivo studies showed the therapeutic activities of clays (Ghadiri, Chrzanowski and

TABLE II

The X-Ray Fluorescence Analysis of the Clays samples.

\begin{tabular}{|c|c|c|c|c|c|}
\hline & \multirow{2}{*}{ Elements } & \multicolumn{4}{|c|}{ Mass \% } \\
\hline & & $\mathrm{C} 1$ & $\mathrm{C} 2$ & $\mathrm{C} 3$ & $\mathrm{C} 4$ \\
\hline 1 & $\mathrm{SiO}_{2}$ & 42.9 & 47.6 & 63.3 & 98.5 \\
\hline 2 & $\mathrm{CaO}$ & 33.8 & 15.6 & 3.96 & 0.226 \\
\hline 3 & $\mathrm{Al}_{2} \mathrm{O}_{3}$ & 11.8 & 12 & 15.5 & 0.874 \\
\hline 4 & $\mathrm{Fe}_{2} \mathrm{O}_{3}$ & 5.19 & 4.62 & 4.29 & 0.123 \\
\hline 5 & $\mathrm{MgO}$ & 4.22 & 16.2 & 3.9 & $\ldots$ \\
\hline 6 & $\mathrm{~K}_{2} \mathrm{O}$ & 1 & 2.96 & 1 & 0.0365 \\
\hline 7 & $\mathrm{TiO}_{2}$ & 0.709 & 0.512 & 0.804 & 0.0065 \\
\hline 8 & $\mathrm{MnO}$ & 0.105 & 0.0837 & 0.0817 & 0.005 \\
\hline 9 & $\mathrm{Cr}_{2} \mathrm{O}_{3}$ & 0.0993 & 0.0086 & $\ldots$ & 0.0028 \\
\hline 10 & $\mathrm{SO}_{3}$ & 0.0545 & 0.0598 & 1.85 & 0.0222 \\
\hline 11 & $\mathrm{Co}_{2} \mathrm{O}_{3}$ & 0.0281 & 0.0172 & 0.0162 & 0.0011 \\
\hline 12 & $\mathrm{SrO}$ & 0.0276 & 0.122 & 0.059 & 0.0006 \\
\hline 13 & $\mathrm{NiO}$ & 0.0235 & 0.0083 & 0.0054 & $\ldots$ \\
\hline 14 & $\mathrm{BaO}$ & 0.018 & 0.028 & 0.637 & $\ldots$ \\
\hline 15 & $\mathrm{~V}_{2} \mathrm{O}_{5}$ & 0.0165 & 0.0199 & 0.0556 & $\ldots$ \\
\hline 16 & $\mathrm{SnO}_{2}$ & 0.0101 & 0.0113 & 0.0091 & 0.0065 \\
\hline 17 & $\mathrm{ZnO}$ & 0.0096 & 0.0092 & 0.0096 & 0.0006 \\
\hline 18 & $\mathrm{CuO}$ & 0.0066 & 0.005 & 0.0071 & 0.0011 \\
\hline 19 & $\mathrm{Rb}_{2} \mathrm{O}$ & 0.0048 & 0.0117 & 0.0055 & 0.0004 \\
\hline 20 & $\mathrm{Y}_{2} \mathrm{O}_{3}$ & 0.0027 & 0.0023 & 0.0032 & $\ldots$ \\
\hline 21 & $\mathrm{WO}_{3}$ & 0.0016 & $\ldots$ & $\ldots$ & $\ldots$ \\
\hline 22 & $\mathrm{Ga}_{2} \mathrm{O}_{3}$ & 0.0016 & 0.0012 & 0.0011 & $\ldots$ \\
\hline 23 & $\mathrm{As}_{2} \mathrm{O}_{3}$ & 0.0015 & 0.0033 & $\ldots$ & 0.0001 \\
\hline 24 & $\mathrm{PbO}$ & 0.0012 & 0.0024 & 0.145 & 0.0005 \\
\hline 25 & $\mathrm{U}_{3} \mathrm{O}_{8}$ & $\ldots$ & 0.001 & $\ldots$ & $\ldots$ \\
\hline 26 & $\mathrm{ThO}_{2}$ & $\ldots$ & 0.0016 & 0.0021 & $\ldots$ \\
\hline 27 & $\mathrm{HfO}_{2}$ & $\ldots$ & 0.0019 & $\ldots$ & $\ldots$ \\
\hline 28 & $\mathrm{Nb}_{2} \mathrm{O}_{5}$ & $\ldots$ & 0.0023 & $\ldots$ & $\ldots$ \\
\hline 29 & $\mathrm{Ta}_{2} \mathrm{O}_{5}$ & $\ldots$ & 0.0028 & 0.0017 & $\ldots$ \\
\hline 30 & $\mathrm{Cr}_{2} \mathrm{O}_{3}$ & $\ldots$ & 0.0086 & 0.0124 & 0.0028 \\
\hline 31 & $\mathrm{Na}$ & $\ldots$ & $\ldots$ & 3.3 & $\ldots$ \\
\hline 32 & $\mathrm{Cl}$ & $\ldots$ & $\ldots$ & 0.708 & 0.0143 \\
\hline 33 & $\mathrm{P}_{2} \mathrm{O}_{2}$ & $\ldots$ & $\ldots$ & 0.251 & $\ldots$ \\
\hline 34 & $\mathrm{Ir}_{2} \mathrm{O}_{3}$ & $\ldots$ & $\ldots$ & 0.0018 & $\ldots$ \\
\hline 35 & $\mathrm{PtO}_{2}$ & $\ldots$ & $\ldots$ & 0.001 & $\ldots$ \\
\hline 36 & $\mathrm{Au}_{2} \mathrm{O}$ & $\ldots$ & $\ldots$ & 0.0005 & $\ldots$ \\
\hline 37 & $\mathrm{TeO}_{2}$ & $\ldots$ & $\ldots$ & $\ldots$ & 0.0008 \\
\hline 38 & $\mathrm{GeO}_{2}$ & $\ldots$ & $\ldots$ & $\ldots$ & 0.0004 \\
\hline
\end{tabular}

Rohanizadeh, 2014b, Marinelli, et al., 2021). The inorganic contents of clay minerals, cations, zeolites, etc., were documented to have the ability to enhance cell proliferation, adhesion and cellular differentiation and uptake (GarcíaVillén, et al., 2020). The results of the present study revealed the effective activity of four types of clays collected from different countries to the skin wounds induced in vivo on Sprague Dawley rats. The healing process characterized by declined wound area measurements and greater wound size reduction percentage as shown in Table 1 and Fig. 2. Whereas, it is obvious from Table 2 and Fig. 3 that all types of clays enclose different quantities of materials as performed by XRD and XRF analysis. Clay collected from Iraq (C1) and the one collected from Azerbaijan (C3) showed the best two results in healing rat's skin wounds $(76 \%$ and $71 \%$ ), respectively. The analysis of $\mathrm{C} 1$ clay showed the presence of Magnesium calcite and Magnesium calcium carbonate (Fig. 3a) whereas Cobalt Tantalum Sulfide was seen in C3 sample (Fig. 3c). Whereas elements analysis by XRF showed the presence of Calcium and Ferric Oxides $\mathrm{C} 1$ sample and Aluminum Oxide in $\mathrm{C} 3$ sample respectively. Other studies reported the same chemical ions and elements in clays (Ghadiri, Chrzanowski and Rohanizadeh, 2014c, Morrison, et al., 2014, Maniatis, et al., 1983) Williams et al. suggested that the biological effects of clays are due to their large surface area that buffers the oxidation state and the water $\mathrm{pH}$ also controlling the solubility of clay derived materials (Williams, et al., 2008).

Clay minerals were reported to establish interactions with biomolecules and permitting new possibilities for delivery of growth factors, matrix proteins and genes in tissue regeneration (Sandri, et al., 2016). The mechanism of wound healing property of the natural clays was documented to be due to regulation of macrophages and recruitment of monocytes into wounds. Moreover, in the healing wounds keratinocytes migrate through the wound area to maintain the epithelial integrity (Incledion, et al., 2021). In another study, the healing process of a synthetic clay has been studied when applied to wounds and the healing process was proposed to be through fibroblast cell proliferation (Ghadiri, et al., 2014a). Furthermore, clay mineral was investigated to promote collagen formation and angiogenesis on skin wounds (García-Villén, et al., 2020)

\section{ConCLusion}

This research has demonstrated the potential of different countries clays as wound healing agents. The difference in their activities was supposed to be due to their different structures; however, more studies are recommended to be performed to reveal the exact mechanism of their action.

\section{REFERENCES}

Arab, S. and Alshikh, A., 2012. The use of clay minerals of the dead sea as drugs. Clay Minerals, 5, pp.112-115.

Carretero, M.I., 2002. Clay minerals and their beneficial effects upon human health. A review. Applied Clay Science, 21, pp.155-163. 
Ferrell, R., 2008. Medicinal clay and spiritual healing. Clays and Clay Minerals, 56, pp.751-760.

García-Villén, F., Souza, I., De Melo Barbosa, R., Borrego-Sánchez, A., Sánchez-Espejo, R., Ojeda-Riascos, S. and Iborra, C.V., 2020. Natural inorganic ingredients in wound healing. Current Pharmaceutical Design, 26, pp.621-641.

Gaskell, E.E. and Hamilton, A.R., 2014. Antimicrobial clay-based materials for wound care. Future Medicinal Chemistry, 6, pp.641-655.

Ghadiri, M., Chrzanowski, W., Lee, W. and Rohanizadeh, R., 2014a. Layered silicate clay functionalized with amino acids: Wound healing application. RSC Advances, 4, pp.35332-35343.

Ghadiri, M., Chrzanowski, W. and Rohanizadeh, R., 2014b. Antibiotic eluting clay mineral (Laponite $\left.{ }^{\circledR}\right)$ for wound healing application: An in vitro study. Journal of Materials Science: Materials in Medicine, 25, pp.2513-2526.

Ghadiri, M., Chrzanowski, W. and Rohanizadeh, R., 2014c. Antibiotic eluting clay mineral (Laponite ${ }^{\circledR}$ ) for wound healing application: An in vitro study. Journal of Materials Science: Materials in Medicine, 25, pp.2513-2526.

Incledion, A., Boseley, M., Moses, R., Moseley, R., Hill, K., Thomas, D., Adams, R., Jones, T. and Bérubé, K., 2021. A new look at the purported health benefits of commercial and natural clays. Biomolecules, 11, p.58.

Maniatis, Y., Simopoulos, A., Kostikas, A. and Perdikatsis, V., 1983. Effect of reducing atmosphere on minerals and iron oxides developed in fired clays: The role of Ca. Journal of the American Ceramic Society, 66, pp.773-781.

Marinelli, L., Cacciatore, I., Eusepi, P., Dimmito, M.P., Di Rienzo, A., Reale, M., Costantini, E., Borrego-Sánchez, A., García-Villén, F. and Viseras, C., 2021. In vitro wound-healing properties of water-soluble terpenoids loaded on halloysite clay. Pharmaceutics, 13, p.1117.

Morrison, K.D., Underwood, J.C., Metge, D.W., Eberl, D.D. and Williams, L.B., 2014. Mineralogical variables that control the antibacterial effectiveness of a natural clay deposit. Environmental Geochemistry and Health, 36, pp.613-631.

Qureshi, M., Khatoon, F. and Ahmed, S., 2015. An overview on wounds, their issue s and natural remedies for wound healing. Biochemistry and Physiology, 4, p.165.

Sandri, G., Bonferoni, M., Rossi, S., Ferrari, F., Aguzzi, C., Viseras, C. and Caramella, C., 2016. Clay minerals for tissue regeneration, repair, and engineering. In: Wound Healing Biomaterials. Elsevier, Amsterdam, Netherlands.

Slamova, R., Trckova, M., Vondruskova, H., Zraly, Z. and Pavlik, I., 2011. Clay minerals in animal nutrition. Applied Clay Science, 51, pp.395-398.

Tang, Q., Shen, S., Liang, J., Liang, G., Ou, X., Wang, L. and Ding, Y., 2005. Pharmacological effects and pharmaceutical application of clay minerals. Journal-Chinese Ceramic Society, 33, p.1036.

Tottoli, E., Dorati, R., Genta, I., Chiesa, E., Pisani, S. and Conti, B., 2020. Skin wound healing process and new emerging technologies for skin wound care and regeneration. Pharmaceutics, 12, p.735.

Viseras, C., Carazo, E., Borrego Sánchez, A., García-Villén, F., Sánchez Espejo, R., Cerezo, P. and Aguzzi, C., 2019. Clay Minerals in Skin Drug Delivery. Springer, Berlin, Germany

Williams, L., 2019. Natural antibacterial clays: Historical uses and modern advances. Clays and Clay Minerals, 67, pp.7-24.

Williams, L.B. and Haydel, S.E., 2010. Evaluation of the medicinal use of clay minerals as antibacterial agents. International Geology Review, 52, pp.745-770.

Williams, L.B., Haydel, S.E., Giese, R.F. Jr. and Eberl, D.D., 2008. Chemical and mineralogical characteristics of French green clays used for healing. Clays and Clay Minerals, 56, pp.437.

Wilson, M.J., 1994. Clay Mineralogy: Spectroscopic and Chemical Determinative Methods. Chapman and Hall, London. 